\title{
"Effect of corporate governance on the financial performance of commercial banks in Nigeria"
}

\begin{tabular}{|c|c|}
\hline \multirow{7}{*}{ AUTHORS } & Lawrence Uchenna Okoye iD https://orcid.org/0000-0001-6999-0100 \\
\hline & R https://publons.com/researcher/1897607/lawrence-u-okoye/ \\
\hline & Felicia Olokoyo (D) https://orcid.org/0000-0003-0176-0194 \\
\hline & R https://publons.com/researcher/2585607/felicia-o-olokoyo/ \\
\hline & Johnson I. Okoh \\
\hline & Felix Ezeji \\
\hline & Rhoda Uzohue \\
\hline ARTICLE INFO & $\begin{array}{l}\text { Lawrence Uchenna Okoye, Felicia Olokoyo, Johnson I. Okoh, Felix Ezeji and } \\
\text { Rhoda Uzohue (2020). Effect of corporate governance on the financial } \\
\text { performance of commercial banks in Nigeria. Banks and Bank Systems, 15(3), } \\
\text { 55-69. doi:10.21511/bbs.15(3).2020.06 }\end{array}$ \\
\hline DOI & http://dx.doi.org/10.21511/bbs.15(3).2020.06 \\
\hline RELEASED ON & Friday, 14 August 2020 \\
\hline RECEIVED ON & Wednesday, 12 June 2019 \\
\hline \multirow[t]{2}{*}{ ACCEPTED ON } & Thursday, 28 May 2020 \\
\hline & $(\mathrm{oc}) \overline{\mathrm{EY}}$ \\
\hline LICENSE & $\begin{array}{l}\text { This work is licensed under a Creative Commons Attribution } 4.0 \text { International } \\
\text { License }\end{array}$ \\
\hline JOURNAL & "Banks and Bank Systems" \\
\hline ISSN PRINT & $1816-7403$ \\
\hline ISSN ONLINE & $1991-7074$ \\
\hline PUBLISHER & LLC “Consulting Publishing Company "Business Perspectives" \\
\hline FOUNDER & LLC "Consulting Publishing Company "Business Perspectives" \\
\hline
\end{tabular}

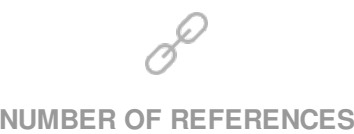

86
NUMBER OF FIGURES

0

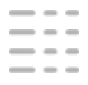

NUMBER OF TABLES

0

(C) The author(s) 2023. This publication is an open access article. 


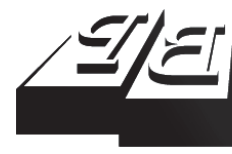

\section{BUSINESS PERSPECTIVES}

LLC "CPC "Business Perspectives" Hryhorii Skovoroda lane, 10, Sumy, 40022, Ukraine www.businessperspectives.org

Received on: $12^{\text {th }}$ of June, 2019 Accepted on: $28^{\text {th }}$ of May, 2020 Published on: $14^{\text {th }}$ of August, 2020

(c) Lawrence Okoye, Felicia Olokoyo, Johnson Okoh, Felix Ezeji, Rhoda Uzohue, 2020

Lawrence Okoye, Ph.D., Lecturer, Department of Banking and Finance, Covenant University Ota, Nigeria. (Corresponding author)

Felicia Olokoyo, Ph.D., Associate Professor of Finance, Department of Banking and Finance, Covenant University Ota, Nigeria.

Johnson Okoh, Ph.D., Senior Lecturer Department of Financial Studies, National Open University of Nigeria, Nigeria.

Felix Ezeji, Ph.D., Head, Department of Financial Standards \& Statutory Compliance, Nigerian Maritime Administration \& Safety Agency, Lagos, Nigeria.

Rhoda Uzohue, B.Sc., Student, Department of Banking and Finance, Covenant University Ota, Nigeria.
This is an Open Access article, distributed under the terms of the Creative Commons Attribution 4.0 International license, which permits unrestricted re-use, distribution, and reproduction in any medium, provided the original work is properly cited.

Conflict of interest statement: Author(s) reported no conflict of interest
Lawrence Okoye (Nigeria), Felicia Olokoyo (Nigeria), Johnson Okoh (Nigeria), Felix Ezeji (Nigeria), Rhoda Uzohue (Nigeria)

\section{EFFECT OF CORPORATE GOVERNANCE ON THE FINANCIAL PERFORMANCE OF COMMERCIAL BANKS IN NIGERIA}

\begin{abstract}
Banks are expected to operate within acceptable standards of governance for consistent profitable operations. They run heavily on customer deposits, which is confidence-driven. Since the quality of governance is critical to winning and retaining customer confidence and patronage, the imperative for good governance practices in banks cannot be overemphasized. This research paper explores the nexus between governance practices and bank profitability in Nigeria. It adopts the size of bank board and directors' stake as proxies for corporate governance, with return on assets and return on equity as representations for financial performance. The research incorporates firm size as a controlled variable. The estimation technique of the Generalized Method of Moments was employed. Evidence from the research reveals that board size, directors' equity, and firm size substantially affect Nigerian banks' financial performance. Besides, the study shows a robust effect of lagged return on equity on the current level of performance. Therefore, the study asserts that governance in business entities strongly affects their financial performance and recommends maintaining optimum board size to minimize boardroom conflicts. It further prescribes that the requirement for substantial equity stake by directors of banking institutions be sustained, as it secures commitment to governance practices that support profitability.
\end{abstract}

\section{Keywords} supervision, administration, performance indicators, firm size, directors' equity

\section{JEL Classification $\quad$ C14, C23, G21, G34}

\section{INTRODUCTION}

Corporate governance is the performance of the task of administration in corporate entities to enhance shareholder value without jeopardizing other interest groups' legitimate expectations, thereby promoting firm sustainability. The underlying principle is to resolve the agency dilemma prevalent in many organizations (Oyarzún, 2011). It is designed to check corporate abuse arising from conflict of interest whereby management, acting as the agent, deploys the organization's resources to advance own interests rather than of the stockholders (principals). The concept of governance in business organizations is neither new to the world of business nor is it new to economic literature but has attracted greater attention since the early 1990s due to the increasing wave of globalization, requirements for increased financial reporting, and rising episodes of corporate failures. For instance, Lahart (2009), Zandi (2009), and Faber (2009) attribute recent emphasis on the subject to series of financial scandals, which caused the collapse of corporate giants around the world early in the millennium. 
Poor corporate governance practice is a cankerworm that affects organizations and has led to the collapse of private and public entities across economic sectors, thereby impairing overall economic performance. It manifests in the sub-optimal deployment of organizations' resources with adverse macroeconomic implications. For instance, despite the successful recapitalization of Nigerian banks ${ }^{1}$ in 2006, Sanusi (2009) avers that poor governance led to systemic capital inadequacy and illiquidity just within three years of the reform, which prompted the take-over of eight banks by the Central Bank of Nigeria $(\mathrm{CBN})$ and subsequent injection of six hundred and twenty (620) billion naira bailout fund in the distressed banks. Of eight banks, only Bank PHB (now Keystone Bank) and Union Bank survived, indicating that mismanagement diverts resources away from productive uses.

Good and adequate corporate governance mechanisms support the going concern principle of business and are critical elements of sustainable growth and development. Business stakeholders like creditors, host communities, suppliers, shareholders, employees, consumers, and the government are happy when businesses are profitably managed because their interests are well catered for when firms generate sufficient cash flows. For instance, the government receives steady revenue in the form of corporate tax, which is required for infrastructural development, and through improved tax revenue, corporate governance can enhance capital formation (Okoye, Evbuomwan, Achugamonu, \& Araghan, 2016). For the banking sector, Okafor (2011) argues that good corporate governance validates management integrity and defines the quality of financial services offered by banks, thereby influencing the sector's overall performance. Besides, sound corporate governance practices stabilize and strengthen financial markets, protect investors, promote firm performance, and attract investments (Cheema \& Din, 2013).

Before introducing the Securities and Exchange Commission (SEC) corporate governance code in 2003 in Nigeria, poor governance practices led to incessant episodes of distress due to declining profitability and erosion of public confidence in banking operations. Banks gave out loans without adequate collateral or no collateral (in some cases), directors gave loans to themselves (Akpan \& Riman, 2012), and staff colluded with outsiders to defraud banks, leading to massive non-performing loans. Though the code was not directed solely at the banking sector, it was designed to check corporate abuses and support sustainable business practices.

Apart from the 2003 landmark corporate governance code, the regulators have introduced some other corporate governance guidelines overtime to regulate Nigeria's financial system. Among them is the corporate governance code for banks (2006) designed by the Central Bank of Nigeria (CBN) to check observed weaknesses in governance practices adopted by banks in the post-consolidation period ${ }^{2}$. There are also the revised CBN prudential guidelines for licensed banks (2010), which contained specific provisions aimed at reinforcing and/or complementing the 2006 corporate governance code ${ }^{3}$. Other extant codes on corporate governance include the PENCOM code of 2008 for pension fund administrators, the NAICOM code (2009) for insurance companies, the Central Bank of Nigeria code (2014), and the National Corporate Governance Code 2016 issued by the Financial Reporting Council of Nigeria.

However, despite the listed corporate governance mechanisms and associated sanctions for non-compliance, there are still episodes of bank failures. For example, of 25 banks that emerged from the banking consolidation, no less than five banks have ceased to exist due to corporate governance infractions, lending credence to a 2003 survey by SEC, which produced evidence of the significant contribution of poor governance to most reported episodes of bank distress in Nigeria (CBN, 2006).

Though there is ample evidence in the literature that improved governance practices enhance financial performance, not many studies from Sub-Saharan African countries have considered how directors' sharehold-

1 Bank capital was raised from 2 billion naira to 25 billion naira between July 2004 and December 2005 to deepen banks' role in the Nigerian economy (Soludo, 2004). Only 25 out of 89 banks emerged from the reform.

2 The 2006 code separated the position of Chief Executive from the office of Board Chairman.

3 The revised CBN prudential guideline (2010) provided for tenure limitation for bank CEOs. 
ing and firm size affect profitability. For instance, if business executives do not have a substantial stake, their commitment to successful outcomes may not be guaranteed. In addition, it can be argued that rapid growth in size may create governance challenges arising from a lack of managerial capacity and discipline. Based on the Generalized Method of Moments, this research estimates how the return on assets and return on equity (profitability ratios) respond to board size and directors' stake in the business. The study introduced a firm size as a controlled variable. The study covers the period 2003-2016.

\section{THEORETICAL FRAMEWORK: STEWARDSHIP THEORY OF CORPORATE GOVERNANCE}

Scholars have developed several theories to explain, evaluate, or predict the relationship between governance and organizational performance. They include social contract, legitimacy, political, agency, resource dependency, stakeholder, and stewardship theories. However, the connection between governance and profitability in business entities is discussed in this research within the stewardship theory context. The theory adopts sociological and psychological approaches to governance.

As opposed to the opportunistic, individualistic, and self-serving assumption of agency theory, stewardship theory projects managers as collectivists, pro-organizational, and trustworthy. The theory depicts managers as stewards who protect and maximize shareholder value through firm performance (Davis, Schoorman, \& Donaldson, 1997). The theory posits that managers find fulfillment from their organizations' success and place the interest of their principals above their own interests. It is, therefore, an organization-centered theory of management. It aims at creating value for shareholders through sustained improvements in business performance. Under the stewardship theory, the positions of Chief Executive Officer (CEO) and Board Chairman are invested in one executive, with a board comprised mostly of in-house members to allow for intimate knowledge of organizational operations and deep commitment to success. This is premised on the assumption that having a single leader creates one channel to communicate business needs to the shareholders and the shareholders' needs to the business, thereby minimizing episodes of confusion and conflict of interest.

\section{LITERATURE REVIEW}

The imperative for sound corporate governance was, at early stages, underscored by the need to safeguard shareholders' interest, but over time, the scope was extended to include protection of other important interests in business organizations (Jizi, Salama, Dixon, \& Startling, 2014). The shift to stakeholder emphasis derives from the argument that these other interests are equally threatened when business organizations are poorly managed.

The significance of sound governance practices to business performance is well established in the literature. For instance, Kolk and Pinske (2010) posit that strong corporate governance structures boost stakeholder confidence, strongly indicating management commitment to the efficient and responsible management of business organizations. Good corporate governance also minimizes exposure to risk for investors and promotes firm performance (Spanos, 2005). Studies by Bae and Goyal (2010), Monda and Georgino (2013), P. Dua and S. Dua (2015), I. Yang, Yan, Li, and H. Yang (2012), and Botosan (2006) show that enhanced stock performance correlates strongly with improvements in corporate governance practices. Ojeka, Iyoha, Ikpefan, and Osakwe (2017) estimated the relationship between governance and stock market behavior in Nigeria and discover the robust positive effect of independent audit committee, financial expertise of audit committee, and board independence on stock price, volume traded, earnings per share, and market capitalization.

The work of Uwuigbe (2011) presents a negative correlation between bank profitability and board size, while directors' interest and degree of corporate disclosure correlate positively with financial performance. It further shows a marked difference between healthy banks' performance and rescued banks but did not substantiate that the performance of banks whose boards are com- 
posed of a mix of foreign and indigenous directors differs significantly from those that do not have foreign directors. However, research by Bae and Goyal (2010) shows that foreign-owned firms record enhanced performance. Boussaada and Karmani (2015) also observed that the proportion of independent directors, institutional shareholders, and foreign investors on bank boards have a robust positive effect on ROA and ROE. However, they present a significant negative impact of board size on both measures of performance. Besides, while CEO duality indicates a strong positive effect on ROA, it shows a non-significant effect on ROE. There is no evidence that bank size strongly impacts the performance of the banks. However, Choi and Hasan (2005) find no substantial impact of foreign directors on Korean banks' profitability. Also, the work of Kumar (2004) did not establish a significant impact of foreign shareholding on the financial performance of Indian firms.

Akinyomi and Olutoye (2015) studied how the proportion of non-executive to executive directors affects bank profitability and observed that profitability is not significantly affected by how bank boards are composed. Besides, they find that board size and directors' equity did not correlate significantly with bank profitability. Conversely, Filip, Vesna, and Kiril (2014) find a strong negative effect of board independence on ROA and ROE. However, board size displays a strong positive correlation with ROA but a non-significant relationship with ROE. They further observe a strong positive association between the tenure of Chief Executive Officer (CEO) and performance. Research by Adigwe, Nwanna, and John (2016) showed that the audit committee and directors' interest enhance profitability, while the bank board's composition does not substantially affect it.

Patibandla (2006) also reveals increased profitability and foreign investment due to improvements in governance practices among Indian firms. Further validation of the performance-enhancing impact of governance on firm performance is captured in Yauri, Muhammad, and Kaoje (2013) who reveal that Chief Executive Officer's tenure, frequency of board meeting, and risk management correlate positively with performance in the Nigerian banking sector. The Colombian study by Orozco and Vargas (2018) reports a substantial positive associ- ation between board size and business reputation but shows that board size correlates negatively with financial performance. However, studies by Belkhir (2009) and Ene and Bello (2016) discover the significant positive effect of board size on bank performance. Besides, Ene and Bello (2016) report that the number of non-executive directors positively correlates with financial performance.

Using Tobin's $Q$ as a proxy for performance, Klapper and Love (2002), Lefort and Urzúa (2008), and Kutubi (2011) provide empirical support performance-enhancing capacity of good corporate governance. Besides, they show that for countries that offer weak protection to investors, corporate governance is critical for improved performance. Lefort and Urzúa (2008) also present a strong positive association between board size and firm performance (proxied as Tobin's Q) for Chilean firms. Kutubi (2011) investigated the influence of the corporate board's size and independence on bank performance in Bangladesh and observed that returns on both equity and assets of banks depend feebly on governance. However, with Tobin's Q as a proxy for performance, the study reveals a robust positive effect of governance on profitability.

Eluyela, Akintimehin, Okere, Ozordi, Osuma, Ilogho, and Oladipo (2018) also examined how profitability responds to board meetings and observe that more frequent board meetings correlate positively with firm performance (proxied as Tobin's Q). The authors also report a non-robust positive relationship between firm performance and board size. Further evidence from the study reveals a strong positive correlation between firm size and performance. The Saudi-based study of Fallatah and Dickins (2012) did not show a significant correlation between corporate governance and profitability with return on assets as a proxy but reports significant positive relationship when Tobin's $Q$ and market value of equity was adopted as proxies for performance, which suggests that the interaction between performance and governance may depend on the proxy used.

Adeusi, Akeke, Aribaba, and Adebisi (2013) observe the non-significant impact of the bank board's size and composition on performance. They further show an adverse effect of external board members on bank profitability. On the other 
hand, Olayiwola (2018) observes that large board retards profitability, while its composition facilitates financial performance but did not establish a robust connection between the size of the audit committee and profitability. In their study, John and Ibenta (2016) reported that the bank board's size and composition adversely affect the financial health of banks. They also observe that directors' equity correlates positively with profitability. Pathan, Skully, and Wickramanayake (2007) also report that large bank board retards performance, while board composition enhances it. The work of Raihan and Hoque (2013) not only validated a strong negative correlation between profitability and governance but also showed that bank age has a strong negative impact on its performance.

Research conducted by Narwal and Jindal (2015) on the nexus between profitability and corporate governance in India reveals a strong correlation between profitability and membership of audit committee, with a weak relationship between profitability and number of board members, regularity of board meetings, and number of external board members. Using least square dummy variable (LSDV) panel data regression and the 2-stage least square estimation techniques, Surya (2016) reveals that independence of corporate board, board committee, and directors' remuneration correlate positively with firm performance, while board size, ownership structure, and financial leverage negatively affect firm performance in India.

Kyereboah-Coleman and Biekpe (2006a) used a mix of listed and non-listed banks to study the effect of board characteristics on bank profitability in Ghana and observe that the bank board size correlates positively with bank performance regardless of listing status. They also show that board independence correlates positively with bank performance despite listing status. Further evidence from the study reveals that CEO duality significantly enhances bank performance for the entire sample, but when the sample is disaggregated into listed and non-listed banks, CEO duality impedes performance. In another study, Kyereboah-Coleman and Biekpe (2006b) examined how corporate governance affects financing decisions based on data generated from 47 quoted companies in Kenya and discover a robust positive association between debt financing and board size. In contrast, board independence has a significant negative relationship with short-term debts. They further report a negative correlation between CEO duality and debt financing.

Okoye, Erin, Ahmed, and Areghan (2017) studied how corporate governance mechanisms affect microfinance institutions' (MFIs) financial sustainability in Nigeria and observe that gender diversity and independence of bank board do not significantly affect financial sustainability. However, the study also reveals that large boards promote financial sustainability. Other investigations that show non-substantial relevance of gender diversity to firm performance include Van Ness, Miesing, and Kang (2010), Sanan (2016), and Gallego-Alvarez, Garcia-Sanchez, and Rodriguez-Dominguez (2010). However, researches by Ongore, Peter, Ogutu, and Bosire (2015), Julizaerma and Sori (2012), and Kilic and Kuzey (2016) report substantial positive transmission of impact from gender diversity to financial performance. Green and Homroy (2018) also validate the existence of a positive relationship between business financial performance and gender diversity (female membership of board committees). Carter, D'Souza, Simkins, and Simpson (2007) specifically observe that female board members positively affect firm performance by participating in audit committees. However, Jadah, Murugiah, and Adzis (2016) showed a strong negative association between female membership of boards and firm performance for Iraqi-listed banks. It also presents strong empirical support for the performance-enhancing feature of board composition.

Research by Mutuku (2016) on Savings and Credit Cooperative Societies (SACCOs) financial performance in Machakos and Anthi river sub-countries reports that board composition, leadership of corporate board, and level of disclosure positively affect financial performance. However, gender did not substantially account for profitability. The study further shows that academic qualification and occupation contribute to the board's capacity to drive performance. The work of Barus, Muturi, Kibati, and Koima (2017), which focused on how the efficiency of management affects the financial performance of Savings and Credit Cooperative Societies (SACCOs) in Kenya, shows that performance is not strongly affected by the efficiency of management. 
Harun (2017) explored how Ethiopian private banks' financial performance responds to extant corporate governance requirements and observes that performance does not respond considerably to board gender diversity and liquidity ratio, but that educational attainment of board members greatly determines performance level in the banks. The research further reveals that number of sub-committees, regularity of board meetings, and firm ownership do not substantially affect the selected banks' performance. Arumona, Erin, Onmonya, and Omotayo (2019) provide strong support for financial education's performance-enhancing capacity. Prior work by Agrawal and Chadha (2005) provides robust evidence that boards that have independent directors with expertise in financial education profit from valuable oversight of their financial reporting practices. Though the early research conducted by Milliken and Martins (1996) also emphasized the relevance of education to group effectiveness, they further observe that problem-solving groups with heterogeneous or diverse educational backgrounds have a stronger impact on performance.

From a study of selected Vietnamese firms, Vo and Phan (2013) observe that female membership of corporate boards, CEO duality, board members' experience, and directors' compensation positively impact return on assets, but performance diminishes with an increase in board size. Another Vietnamese study by Le and Thi (2016) reports that board size, chairman ownership, and concentrated ownership promote profitability (proxied as Tobin's Q), while leverage negatively correlates with firm performance. However, CEO duality and CEO ownership did not show a significant relationship with firm performance.

Using the data from five quoted banks in Nigeria for 2007-2014, Olokoyo, Adegboye, Okoye, Evbuomwan, and Adebo (2019) analyzed how selected internal corporate governance components affect bank performance. The result indicates support for persistence or lag effect of governance on firm performance. It shows a strong adverse effect of lagged board composition and board size on bank performance. Bebeji, Mohammed, and Tanko (2015) report a strong negative effect of board size on ROA and ROE and the strong positive effect of board composition on both per- formance measures. Evidence from Isik and Ince (2016) indicates a significant positive effect of board size on operating return on assets (OROA) and return on assets (ROA). It further reveals the non-significant negative effect of board composition on OROA but a significant negative effect on ROA.

Based on a panel study of 329 microfinance institutions (MFIs) from 73 countries, Strøm, D’Espallier, and Mersland (2014) provide empirical support for a positive relationship between female CEO and female board chair, and the performance of MFIs but did not provide evidence that improved corporate governance drives firm performance. The research by Roodposhti and Chasmi (2010) indicates that business ownership and independent boards correlate negatively with firm earnings in Iran. Shivaani, Jain, and Yadav (2017) also showed the negative influence of board size and board committees on return on assets and equity. It further reports that the presence of outside directors and whistleblowers enhances financial performance.

From a study of fifty largest Chinese banks between 2003 and 2010, Liang, $\mathrm{Xu}$, and Jiraporn (2013) discovered the frequency of board meetings and the number of independent directors strongly enhance both quality of bank assets and bank performance, though board size was shown to correlate negatively with performance. They also observe that the bank board's political affiliation negatively affects both the performance and asset quality of the banks. The work of Adekunle and Aghedo (2014), which studied financial performance and corporate governance in selected firms in Nigeria, reveals robust positive impact transmission from board size and its composition to firm performance. However, the study did establish an inverse relationship between ownership concentration and return on assets. Research by Usman and Yero (2012) also reveals a negative impact of ownership concentration on earnings management in listed conglomerates in Nigeria.

A study of the Sri Lankan financial services sector conducted by Thuraisingam (2013) shows no substantial association between governance and firm performance. Tata and Sharma (2012) report that board structures, business ownership, and corpo- 
rate disclosures do not correlate significantly with Indian business organizations' profitability. Also, the work of Sarpal and Singh (2013) did not establish a robust relationship between corporate board and performance. On the other hand, a study of the Jordanian insurance sub-sector carried out by Salim and Iskandar (2017) indicates that the number of external directors and foreign ownership strongly improves firm performance, while the separation of CEO and board chair roles retard it.

In a study of 103 quoted firms from Ghana, Kenya, South Africa, and Nigeria, Kyereboah-Coleman (2007) observe that while board size, board independence, and CEOs tenure have a strong positive effect on corporate profitability, consolidation of the position of the CEO and board chairman retard performance. It also reveals that the audit committee's size, frequency of audit committee meetings, and institutional shareholdings positively affect market performance and firm valuation. The study further suggests that the interaction between governance and firm profitability derives substantially from how variables are approximated. For instance, while board size did not show a strong positive correlation with ROA, it correlates strongly with Tobin's Q. Also, institutional shareholding correlates negatively with ROA but positively with Tobin's Q. For the frequency of the audit committee meeting, while the association is strongly positive with Tobin's Q, it is nearly independent of ROA.

Goel (2018) conducted a multi-sectoral analysis of the effectiveness of corporate governance practices adopted by Indian firms over two reform periods of 2012-2013 and 2015-2016. The study reveals that post-reform improvements in governance practices significantly impact financial performance only in the 2012-2013 period. Sani, Aliyu, and Bakare (2019) estimated the impact of governance on financial performance in Nigerian banking and observed a strong positive effect of management shareholding on financial performance, suggesting that management commitment to firm performance is closely tied to their level of investment in the business.
This literature review shows that though financial performance and corporate governance have remained very topical, empirical evidence on how firm performance is affected by governance is rather mixed, an indication that there is no straightjacket connection between the financial performance of business organizations and how they are governed. It shows that the interaction between performance and governance derives from the proxies used for the variables. Finally, it was observed that despite numerous research studies on corporate governance and profitability, very few studies have focused on how directors' shareholding and firm size affect profitability, and therein lies the novelty of this study.

\section{METHODS AND HYPOTHESES}

The study is quantitative and adopts the ex-post facto design. Financial statements of the selected banks for the period 2003-2016 provided data for the research. Following from the objectives of the study, the Generalized Method of Moments $(\mathrm{GMM})^{4}$ analytical technique based on STATA 13 statistical procedure was used to analyze the data.

\subsection{Model specification}

The modified version of Miyajima, Omi, and Sato (2003) adopted by Kyereboah-Coleman and Biekpe (2006a) to estimate the nexus between corporate governance and bank performance was used in this study. The model in Kyereboah-Coleman and Biekpe (2006a) is stated in its explicit form as:

$$
Y_{i t}=\beta_{0}+\beta_{1} G_{i t}+L S T_{i}+\mu_{t}
$$

where $Y_{i t}$ - measures of firm performance; $G_{i t}-$ vector of corporate governance proxies: bank size and board composition; $L S T_{i}$-dummy introduced to ascertain if positions of CEO and board chairman are consolidated or separated, CEO tenure, and controlled variables: firm size and debt structure of the bank; $\beta_{0}$ - constant; $\beta_{1}$ - parameter to be estimated; $\mu_{t}$ - error term.

4 Generalized Method of Moments (GMM) was used to estimate the parameters of the model because it solves the problem of endogeneity so that group-specific time-invariant factors do not affect parameter estimates and reduces serial correlation problem to the minimum. Zsohar (2012) defines GMM as a semi-parametric estimation framework that allows only introducing restrictions implied in economic theory. 
The above model was modified in line with the variables examined in the study as follows:

Model 1:

$$
\begin{aligned}
& R O A_{t}=\beta_{0}+\beta_{1} \text { BSIZE }_{t}+ \\
& +\beta_{2} D I N T_{t}+\beta_{3} \text { LTAS }_{t}+\mu_{t} .
\end{aligned}
$$

\section{Model 2:}

$$
\begin{aligned}
& R O E_{t}=\beta_{0}+\beta_{1} \text { BSIZE }_{t}+ \\
& +\beta_{2} \operatorname{DINT}_{t}+\beta_{3} \text { LTAS }_{t}+\mu_{t},
\end{aligned}
$$

where $R O A_{t}$ - return on assets; $R O E_{t}$ - return on

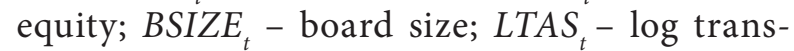
formation of total assets (proxy for firm size); $D I N T_{t}$ - directors' equity or interest; $\beta_{0}$ - constant. $\beta_{1}-\beta_{3}-$ coefficient to be estimated; $\mu$ - error term.

\subsection{Operationalization of variables}

Board size represents the total board members. It includes executive and non-executive directors.

Directors' equity is measured as total number of shares held by directors divided by total number of shares issued.

Return on equity is measured as profit after tax or net profit divided by shareholders' equity.

Return on assets is measured as profit after tax or net profit divided by total assets.

Firm size represents total assets of each bank.

\subsection{Research hypotheses}

The null form of the hypotheses formulated for this study is stated as follows:

Table 1. Descriptive statistics of the variables
$H_{0} 1$ : Corporate governance does not have a significant effect on return on assets (ROA).

$\mathrm{H}_{0}$ 2: Return on equity (ROE) is not significantly affected by corporate governance practices.

The models specified in equations (2) and (3) are used to test these hypotheses.

\section{RESULTS}

Estimates from the econometric test are presented and discussed in this section. The data's statistical properties were analyzed to show its basic descriptive parameters, while correlation among the variables was examined to reveal how they interact with one another.

\subsection{Descriptive statistics}

The descriptive statistics of the data are presented in Table 1.

Table 1 observed that for eight selected banks, average $R O E$ was about 11.6 percent, while the series deviates from the mean by 19.8 percent. This implies that ROE can vary from its mean by about 19.8 percent. The maximum and minimum values of $R O E$ generated over the study period are -86 percent and 89 percent, respectively. For return on assets $(R O A)$, a mean of 2.1 percent was observed with a standard deviation of 7 percent. The minimum and maximum values of $R O A$ are -53 percent and 32 percent, respectively.

For board size, about 13 was observed, with a standard deviation of about 3. The banks have minimum and maximum board sizes of 6 and 19, respectively. Directors' equity or interest stood at about 26.7 percent of total shareholdings in the banks, with a standard deviation of about 19.2

Source: Author's computation from published accounts of the studied banks using STATA.

\begin{tabular}{l|c|c|c|c|c}
\hline \multicolumn{1}{c|}{ Variable } & Obs. & Mean & Std. dev. & Min & Max \\
\hline ROA & 112 & 0.020932 & 0.072829 & -0.53125 & 0.3241 \\
ROE & 112 & 0.116464 & 0.197927 & -0.86844 & 0.89654 \\
BSIZE & 112 & 12.94643 & 2.884689 & 0 \\
DINT & 112 & 0.266974 & 0.192371 & 0.0342 & 19 \\
LTAS & 112 & 9.480061 & 0.285563 & 9.018478 & 9.999191 \\
\hline
\end{tabular}


percent. Minimum and maximum shareholdings by directors stood at 3.4 percent and 85 percent of total issued shares. The average total assets held by the banks were 9.48 , with a standard deviation of about 0.286 . The minimum and maximum values stood at 9.02 and 10.00 , respectively.

\subsection{Correlation matrix}

The matrix in Table 2 shows how the variables in the model interact with one another. However, for this study, the emphasis is on the relationship between the dependent variable and the independent variables. The diagonal of the matrix is a set of 1 because the correlation between a variable and itself is always 1 . In other words, a correlation matrix is symmetrical. The correlation coefficient ranges between -1 and 1 .

Table 2. Correlation matrix for the variables

Source: Author's computation from annual reports of studied banks using

\begin{tabular}{l|c:c|c|c|c}
\hline Variable & ROA & ROE & BIZE & DINT & LTAS \\
\hline$R O A$ & 1 & - & - & - & - \\
\hline$R O E$ & 0.2466 & 1 & - & - & - \\
\hdashline$B S I Z E$ & 0.2457 & -0.0598 & 1 & - & - \\
\hline$D I N T$ & -0.0943 & 0.0072 & -0.0813 & 1 & - \\
\hline LTAS & 0.0304 & -0.2262 & 0.1202 & 0.1582 & 1 \\
\hline
\end{tabular}

The correlation matrix presented in Table 2 shows a weak positive association between $R O A$ and $B S I Z E$, with a correlation coefficient of 0.2457 . It also shows a more feeble negative relationship be- tween $R O A$ and DINT, with correlation coefficient approximating -0.1 . Furthermore, with a coefficient of 0.0304 , the matrix shows a weak positive relationship between ROA and TAS.

The correlation test presents an inverse connection between ROE and BSIZE, with a coefficient of -0.0598 . A very weak positive relationship between $R O E$ and DINT was also observed, with a coefficient of 0.0072 . Finally, the result shows a weak negative association between $R O E$ and TAS, with a coefficient of -0.2262 .

From the correlation matrix, the relationship among the independent variables does not suggest multi-collinearity, which indicates that the data can further be processed for policy decisions. This is indicated by the reasonably moderate values of the associated coefficients.

\subsection{Regression analysis (Generalized Method of Moments)}

The regression estimates based on the Generalized Method of Moments are presented in Tables 3 and 4 .

Model 1: Dependent variable (ROA): system dynamic panel-data estimation

Model 2: Dependent variable (ROE): system dynamic panel-data estimation

Table 3. Regression estimates for return on assets $(R O A)$

\begin{tabular}{|c|c|c|c|c|c|c|}
\hline \multirow{2}{*}{$\begin{array}{ll} & \text { ROA } \\
R O A & \end{array}$} & \multirow{2}{*}{$\frac{\text { Coef. }}{-}$} & \multirow{2}{*}{ Std. err } & \multirow{2}{*}{$\frac{\mathbf{Z}}{-}$} & \multirow{2}{*}{$\frac{p>|Z|}{-}$} & \multicolumn{2}{|c|}{ [95\% conf. interval] } \\
\hline & & & & & Lower limit & Upper limit \\
\hline$R O A(-1)$ & 0.0263495 & 0.0838265 & 0.31 & 0.7530 & -0.1379473 & 0.1906464 \\
\hline$B S I Z E$ & -0.0107527 & 0.0029008 & 0.761 & 0.3450 & 0.0050672 & 0.0164382 \\
\hline$D I N T$ & 0.0479112 & 0.0459867 & 3.04 & 0.0297 & 0.1380435 & 0.0422211 \\
\hline LTAS & 0.0610397 & 0.0297461 & 2.05 & 0.0400 & 0.0027384 & 0.1193409 \\
\hline CONST & -0.6865451 & 0.2779649 & -2.47 & 0.0140 & -1.231346 & -0.141744 \\
\hline
\end{tabular}

Table 4. Regression estimates for return on equity $(R O E)$

Source: Author's computation from annual reports of studied banks using STATA.

\begin{tabular}{|c|c|c|c|c|c|c|}
\hline ROE & Coeff. & Std. err & $\mathbf{Z}$ & $p>|Z|$ & \multicolumn{2}{|c|}{ [95\% conf. interval] } \\
\hline$R O E$ & - & - & - & & Lower limit & Upper limit \\
\hline$R O E(-1)$ & 0.3286716 & 0.0821818 & 4.0 & 0.0000 & 0.1675982 & 0.4897449 \\
\hline$B S I Z E$ & -0.0048106 & 0.006885 & -0.7 & 0.4850 & -0.018305 & 0.0086838 \\
\hline DINT & 0.0511786 & 0.1052611 & 2.31 & 0.0627 & 0.1551295 & 0.2574866 \\
\hline LTAS & 0.0666501 & 0.0709301 & 2.94 & 0.0347 & -0.0205671 & 0.0723703 \\
\hline CONST. & 0.7537662 & 0.6597117 & 1.14 & 0.253 & -0.5392449 & 2.046777 \\
\hline
\end{tabular}




\section{DISCUSSION}

The regression analysis result using the Generalized Method of Moments (GMM) presented in Table 3 evaluates the effect of the independent variables on corporate governance. From the estimates, lagged ROA (lag 1) did not significantly affect the current $R O A$. This indicates that its own past developments or trends do not strongly determine the current behavior of return on assets.

The beta coefficient for BSIZE shows a negative value of -0.0107527 , which suggests a 1 percent addition to board size will cause a 0.01 percent decrease in ROA. The negative result indicates that an increase in board size can be counter-productive, implying that as more shareholders get elected to bank boards, conflict of interests may arise, leading to boardroom squabbles and other negative practices that impede the efficiency of operations. This result, though not significant ( $p$-value $>0.05$ ), is consistent with the findings of Fallatah and Dickens (2007), Kyereboah-Coleman (2007b), Kutubi (2011), Uwuigbe (2011), Orozco and Vargas (2018), but counters the outcomes in Kyereboah-Coleman and Biekpe (2006a), Filip, Vesna, and Kiril (2014), Adekunle and Aghedo (2014), Ene and Bello (2016), and Isik and Ince (2016) who present the strong positive effect of governance on performance. It is also not consistent with the findings of Vo and Phan (2013), Bebeji, Mohammed, and Tanko (2015), Raihan and Hoque (2013), Liang, $\mathrm{Xu}$, and Jiraporn (2013), Boussaada and Karmani (2015), Shivaani, Jain, and Yadav (2017), and Olokoyo, Adegboye, Okoye, Evbuomwan, and Adebo (2019) who show a strong negative effect of corporate governance on bank performance.

The result further shows significant positive effect DINT on ROA at a 5 percent level of significance, with a coefficient of 0.0479 . This suggests that a unit increase in directors' equity or interest will increase firm performance by 0.0479 units. The result for directors' equity implies that directors get more committed to ensuring that organizations are profitably managed when they stand to lose more should the organizations fail. This validates the find- ings of Uwuigbe (2011), Adigwe, Nwanna, and John (2016), and Sani Aliyu, and Bakare (2019). However, there is no contrary evidence from the reviewed literature.

The result indicates that $R O A$ will rise by 0.06 percent for total assets if bank assets are increased by 1 percent. This relationship is significant at 5 percent. The positive relationship implies that as bank assets increase, more funds are available for direct investments and funding private and public sector activities, thereby further enhancing the earning capacity of bank assets. This result aligns with Isik and Ince (2014), Kyereboah-Coleman and Biekpe (2006a), Vo and Phan (2013), but counters the non-significant effect reported in Boussaada and Karmani (2015).

The Wald chi $^{2}$ accounts for the general significance of the model. With $p$-value $<0.05$, it shows that the independent variables significantly explain the phenomenon under investigation.

Based on the above results, the null hypothesis that corporate governance does not significantly affect the return on assets $(R O A)$ is rejected.

Concerning the interaction between return on equity and dimensions of corporate governance examined in this research, Table 4 shows that lagged $R O E$ (lag 1) strongly enhances current $R O E$. The lag effect of $R O E$ on its current performance indicates that its own previous innovations significantly influence the current behavior of return on equity. The coefficient for $B S I Z E\left(\beta_{1}\right)$ shows a negative value of -0.0048106 , indicating that a unit increase in board size leads to a decrease in bank profitability (proxied as return on equity) by 0.005 units. This result implies that large boards inhibit performance and, therefore, counters the argument that large boards offer high-quality decisions when drawing from more directors' experience. However, since the probability of the Z-statistic $(0.485)$ is greater than 5 percent ( $p$-value $>0.05)$, this observation is not significant. Though this result affirms the outcomes in Uwuigbe (2011), Thuraisingam (2013), Akinyomi and Olutoye (2015), and Filip, Vesna, and Kiril (2014), it is not in agreement with Pathan, Skully, and 
Wickramanayake (2007), Ajala, Amuda, and Arulogun (2012), Ayorinde, Toyin, and Leye (2012), Liang, $\mathrm{Xu}$, and Jiraporn (2013), John and Ibenta (2016), Bebeji, Mohammed, and Tanko (2015), Boussaada and Karmani (2015), Filip, Vesna, and Kiril (2015), and Shivaani, Jain, and Yadav (2017) who show that large boards strongly reduce bank profitability.

For DINT, the coefficient $\beta_{2}$ of 0.0511786 indicates a positive effect of directors' interest on $R O E$. Specifically, it shows that as directors' interest is increased byl percent, $R O E$ is expected to increase by 0.05 per+cent. With a $p$-value of 0.0627 , this result is significant at 10 percent. This result aligns with Uwuigbe (2011) and John and Ibenta (2016) but contradicts the finding of Akinyomi and Olutoye (2015) that directors' equity does not significantly affect performance.
The result for TAS also shows a strong positive effect of total bank assets on ROE, thereby further validating the result that an increase in bank assets leads to an increase in banks' profitability. From the result, an increase of 1 percent in bank assets generates about 0.067 percent in $R O E$. The positive effect of bank assets on return on equity supports Boussaada and Karmani (2015).

The Wald $\mathrm{chi}^{2}$ indicates that the selected elements of corporate governance strongly explain bank profitability. With prob. (Wald $\mathrm{chi}^{2}$ ) $<0.05$, the model is considered fit for policy formulation.

From the above result, the null hypothesis that corporate governance does not significantly affect the return on equity (ROE) is rejected.

\section{CONCLUSION}

The study shows that the current behavior of ROA is not dependent on its own past innovations. However, the current level of ROE significantly derives from its previous developments or trends. It also shows that a large bank board is an obstacle to performance. The negative impact of board size on both ROA and ROE (proxies for corporate governance) aligns with the agency theory of Jensen and Meckling (1976), which states that small boards can improve the financial performance of organizations because they are less prone to operational inefficiency, problems of moral hazard, nonchalance/lack of commitment, and overbearing influence of Chief Executive Officers that characterize large-sized boards. However, it contradicts the resource dependence theory of Pfeffer and Salancik (1978), which posits that large boards can enhance firm performance through improvement in the quality of perspectives, deliberations and opinions, and access to more informed or better quality decisions (Belkhir, 2009; C. Dalton \& D. Dalton, 2005).

The study further shows that directors are committed to sound governance practices when they have high stakes. Such practices support the profitable management of business entities. Finally, the study shows that banks with a robust asset base are likely to record enhanced financial performance.

Based on the above findings, the study asserts that increased bank profitability significantly derives from good governance and, therefore, recommends maintaining adequate governance mechanisms to ensure that banks are profitably managed. For instance, the requirement for a substantial equity stake by directors of banking institutions should be sustained. By their unique nature, banks are highly levered institutions because of massive deposit liabilities in their portfolio. If banks are to run entirely on debt, the board's commitment to monitoring top management may be compromised. Minimum paidup bank capital should be periodically reviewed to support the maintenance of optimum bank assets. Also, board size should be maintained at an optimal level to enhance performance.

\section{ACKNOWLEDGMENT}

The authors acknowledge the support of Covenant University towards the publication of this paper. 


\section{REFERENCES}

1. Adekunle, S. A., \& Aghedo, E. M. (2014). Corporate governance and financial performance of selected quoted companies in Nigeria. European Journal of Business and Management, 6(9), 4-16. Retrieved from https://www.iiste.org/Journals/index.php/EJBM/article/ view/11758/12113

2. Adeusi, S., Akeke, N., Aribaba, F., \& Adebisi, O. (2013). Corporate governance and firm financial performance: Do ownership and board size matter? Academic Journal of Interdisciplinary Studies, 2(3), 251-258. Retrieved from https:// www.mcser.org/journal/index.php/ ajis/article/view/1411/1436

3. Adigwe, P. K., Nwanna, I. O., \& John, E. I. (2016). Effect of corporate governance mechanism on the financial performance of banks in Nigeria. NG-Journal of Social Development, 5(2), 41-50. Retrieved from https://www.arabianjbmr.com/ pdfs/NGJSD_VOL_5_2/5.pdf

4. Agrawal, A., \& Chadha, S. (2005). Corporate governance and accounting scandals. Journal of Law and Economics, 48(1), 371-406. http://dx.doi.org/10.1086/430808

5. Ajala, O. A., Amuda, T., \& Arulogun, L. (2012). Evaluating the effects of corporate governance on the performance of the Nigerian banking sector. Review of Contemporary Business Research, 1(1), 32-42. Retrieved from http:// rcbrnet.com/journals/rcbr/Vol_1_ No_1_December_2012/4.pdf

6. Akiyomi, O. J., \& Olutoye, E. A. (2015). Corporate governance and profitability of Nigerian banks. Asian Journal of Finance and Accounting, 7(1), 172-182. https:// doi.org/10.5296/ajfa.v7i1.6543

7. Akpan, E. S., \& Riman, H. B. (2012) Does corporate governance affect bank profitability? Evidence from Nigeria. American International Journal of Contemporary Research, 2(7), 135-145. Retrieved from https://www.academia. edu/2077759/Does_Corporate_ Governance_affect_Bank_Profitability_Evidence_from_Nigeria
8. Aromona, J., Erin, O., Onmonya, L., \& Omotayo, V. (2019). Board financial education and firm performance: Evidence from the healthcare sector in Nigeria. Academy of Strategic Management Journal, 18(4). Retrieved from https://www.abacademies.org/ articles/board-financial-educationand-firm-performance-evidencefrom-the-healthcare-sector-innigeria-8278.html

9. Ayorinde, A. O., Toyin, A., \& Leye, A. (2012). Evaluating the effect corporate governance on the performance of the Nigerian banking sector. Review of Contemporary Business Research, 1(1), 32-42. Retrieved from http:// rcbrnet.com/vol-1-no-1-december2012-abstract-4-rcbr

10. Bae, K. H., \& Goyal, V. K. (2010). Equity market liberalization and corporate governance. Journal of Corporate Finance, 16(5), 609-621. Retrieved from http://citeseerx.ist. psu.edu/viewdoc/download?doi=10 .1.1.581.4492\&rep $=$ rep $1 \&$ type $=$ pdf

11. Barus, J. J., Muturi, W., Kibati, P., \& Koima, J. (2017). Effect of management efficiency on financial performance of savings and credit societies in Kenya. Journal of Strategic Management, 2(1), 92-104. Retrieved from https://ajpojournals. org/journals/index.php/JSM/article/ view/287

12. Bebeji, A., Mohammed, A., \& Tanko, M. (2015). The effect of board size and composition on the financial performance of banks in Nigeria. African Journal of Business Management, 9(16), 590-598. http:// dx.doi.org/10.5897/AJBM2015.7797

13. Belkhir, M. (2009). Board of director's size and performance in the banking industry. International Journal of Managerial Finance, 5(2), 201-221. https://doi. org/10.1108/17439130910947903

14. Botosan, C. A. (2006). Disclosure and the cost of capital: What do we know? Accounting and Business Research, 36(1), 31-40. https://doi.or g/10.1080/00014788.2006.9730042
15. Boussaada, R., \& Karmani, M. (2015). Did board of directors have an impact on MENA bank performance? International Journal of Economics and Finance, 7(4), 46-56. https://doi.org/10.5539/ijef. v7n $4 \mathrm{p} 46$

16. Carter, D. A., D'Souza, F. D., Simkins, B. J., \& Simpson, W. G. (2007). The Diversity of Corporate Board Committees and Firm Financial Performance. https://doi. org/10.2139/ssrn.1106698

17. Cheema, K. U., \& Din, M. S. (2013) Impact of corporate governance on the profitability of firms: A case study of cement industry in Pakistan. Journal of Business Management Sciences, 1(4), 44-46. Retrieved from http://pubs.sciepub. com/jbms/1/4/1/index.html

18. Choi, S., \& Hasan, I. (2005). Ownership, Governance, and Bank Performance: Korean Experience. Financial Markets, Institutions and Instruments, 14(4), 215-242. http://dx.doi.org/10.1111/j.09638008.2005.00104.x

19. Dalton, C. M., \& Dalton, D. R. (2005). Board of directors: Utilizing empirical evidence in developing practical prescriptions. British Journal of Management, 16(1), 9197. https://doi.org/10.1111/j.14678551.2005.00450.x

20. Davis, J. H., Schoorman, F. D., \& Donaldson, L. (1997). Toward a stewardship theory of management. Academy of Management Review, 22(1), 20-47. Retrieved from https:// www.jstor.org/stable/259223

21. Dua, P., \& Dua, S. (2015). A review article on corporate governance reforms in India. International Journal of Research, 2(2), 806-835. Retrieved from http://citeseerx.ist. psu.edu/viewdoc/download?doi=10 1.1.823.6879\&rep=rep1\&type $=$ pdf

22. Eluyela, D. F., Akintimehin, O. O., Okere, W., Ozordi, E., Osuma, G. O., Ilogho, S. E., \& Oladipo, O. A. (2018). Board meeting frequency and firm performance: Examining the nexus in the Nigerian deposit money banks. Heliyon, 4(10). https://doi.org/10.1016/j.heliyon.2018.e00850 
23. Ene, E. E., \& Bello, A. I. E. (2016). The effect of corporate governance on bank's financial performance in Nigeria. IOSR Journal of Business and Management (IOSR-JBM), 18(11), 99-107. Retrieved from https://pdfs.semanticscholar.org/b3 55/7a1dc4448d4979e94582332d7d4 407adc50f.pdf

24. Faber, D. (2009). And Then The Roof Caved In. New Jersey: John Wiley and Sons Inc.

25. Fallatah, Y., \& Dickins, D. (2012). Corporate governance and firm performance and value in Saudi Arabia. African Journal of Business Management, 6(36), 1002510034. Retrieved from https:// academicjournals.org/article/article1380795217_Fallatah\%20and\%20 Dickins.pdf

26. Filip, F., Vesna, M., \& Kiril, S. (2014). Corporate governance and bank performance: Evidence from Macedonia. Economic Analysis, 47(1-2), 76-99. Retrieved from https://www.researchgate.net/publication/313640657_Corporate_Governance_and_Bank_Performance_ Evidence_from_Macedonia

27. Gallego-Álvarez, I., García-Sánchez, I. M., \& Rodríguez-Dominguez, L. (2010). The influence of gender diversity on corporate performance. Revista de Contabilidad, 13(1), 5388. https://doi.org/10.1016/S11384891(10)70012-1

28. Goel, P. (2018). Implications of corporate governance on financial performance: An analytical review of governance and social reporting reforms in India. Asian Journal of Sustainability and Social Responsibility, 3(4), 1-21. https://doi. org/10.1186/s41180-018-0020-4

29. Green, C. P., \& Homroy, S. (2018). Female directors, board committees and firm performance. European Economic Review, 102(C), 19-38. https://doi.org/10.1016/j.euroecorev.2017.12.003

30. Harun, A. (2017). Corporate Governance and its Effect on Financial Performance of the Ethiopian Private Commercial Banks (Master's Thesis). Addis Ababa University.
31. Isik, O., \& Ince, A. R. (2016). Board size, board composition and performance: An investigation on Turkish banks. International Business Research, 9(2), 74-84. https://doi.org/10.5539/ibr.v9n2p74

32. Jadah, H. M., Murugiah, L. A/P., \& Adzis, A. B. (2016). The effect of board characteristics on Iraqi banks performance. International Journal of Academic Research in Accounting, Finance and Management Sciences, 6(4), 205-214. Retrieved from http:// hrmars.com/hrmars_papers/Article_20_The_Effect_of_Board_Characteristics.pdf

33. Jensen, M. C., \& Meckling, W. H. (1979). Theory of the firm: managerial behavior, agency costs, and ownership structure. Journal of Financial Economics, 3(4), 305-360. Retrieved from https://uclafinance. typepad.com/main/files/jensen_76. pdf

34. Jizi, M. I., Salama, A., Dixon, R., \& Stratling, R. (2014). Corporate governance and corporate social responsibility disclosure: Evidence from the US banking sector. Journal of Business Ethics, 125(4), 601-615. Retrieved from https:// www.researchgate.net/publication/271630353_Corporate_Governance_and_Corporate_Social_Responsibility_Disclosure_Evidence_ from_the_US_Banking_Sector

35. John, E. I., \& Ibenta, S. N. (2016). Corporate governance and the performance of Nigerian banks. International Journal of Economics, Finance and Management Sciences, 4(2), 39-45. https://doi. org/10.11648/j.ijefm.20160402.11

36. Julizaerma, M. K., \& Sori, Z. M. (2012). Gender diversity in the boardroom and firm performance of Malaysian public listed companies. Procedia-Social and Behavioral Sciences, 65, 1077-1085. Retrieved from https://core.ac.uk/ download/pdf/81927397.pdf

37. Kılıç, M., \& Kuzey, C. (2016). The effect of board gender diversity on firm performance: evidence from Turkey. Gender in Management: An International Journal, 31(7), 434-455. https://doi.org/10.1108/GM-102015-0088
38. Klapper, L. F., \& Love, I. (2002). Corporate governance, investor protection and performance in emerging markets (Policy Research Paper No. 2818). World Bank. Retrieved from http://hdl.handle. net/10986/14319

39. Kolk, A., \& Pinkse, J. (2010). The integration of corporate governance in corporate social responsibility disclosures. Corporate Social Responsibility and Environmental Management, 17(1), 15-26. https:// doi.org/10.1002/csr.196

40. Kumar, J. (2004). Does corporate governance influence firm value? Evidence from Indian firms. The Journal of Entrepreneurial Finance \& Business Ventures, 9(2), 61-91. Retrieved from https://digitalcommons.pepperdine.edu/jef/vol9/ iss $2 / 4 /$

41. Kutubi, S. S. (2001). Board of director's size, independence and performance: An analysis of private commercial banks in Bangladeshi. World Journal of Social Sciences, 1(4), 159-178. Retrieved from https:// www.researchgate.net/publication/228519192_Board_of_Director's_Size_Independence_and_Performance_An_Analysis_of_Private_ Commercial_Banks_in_Bangladesh

42. Kyereboah-Coleman, A., \& Biekpe, N. (2006a). Do boards and CEOs matter for bank performance: A comparative analysis of banks in Ghana. http://dx.doi.org/10.22495/ cocv4ilp10

43. Kyereboah-Coleman, A., \& Biekpe, N. (2006b). Corporate governance and the performance of microfinance institutions in Ghana (Working Paper No. 4330-05). UGBS Legon.

44. Kyereboah-Coleman, A. (2007). Corporate governance and firm performance in Africa: A dynamic panel analysis. Paper prepared for the International Conference on Corporate Governance in Emerging Markets, Global Corporate Governance Forum (GCGF) and Asian Institute of Corporate Governance (AICG). Sabanci University, Istanbul, Turkey. Retrieved from https://pdfs.semanticscholar.org/14ae/1ccbacaced1dce 3c9003b61e3f73b1cee543.pdf 
45. Lahart, J. (2009, July 8). The current recession: A downturn sized up. The Wall Street Journal.

46. Le, N. N. D., \& Thi, N. N. D. (2016). An examination of the relationship of corporate governance to firm performance: Empirical evidence from Vietnamese listed companies. International Journal of Financial Research, 7(4), 190-197. Retrieved from https://ideas.repec.org/a/jfr/ ijfr11/v7y2016i4p190-197.html

47. Lefort, F., \& Urzúa, F. (2008). Board independence, firm performance and ownership concentration: Evidence from Chile. Journal of Business Research 61(6), 615-622. https://doi. org/10.1016/j.jbusres.2007.06.036

48. Liang, Q., Xu, P., \& Jiraporn, P. (2013). Board characteristics and Chinese bank performance. Journal of Banking and Finance, 37(8), 2953-2968. Retrieved from https://pennstate.pure.elsevier. com/en/publications/board-characteristics-and-chinese-bankperformance

49. Milliken, F. J., \& Martins, L. L. (1996). Searching for common threads: Understanding the multiple effects of diversity in organizational groups. Academic Management Review, 21(2), 402433. Retrieved from https://www. jstor.org/stable/258667?seq=1

50. Miyajima, H., Omi, Y., \& Sato, N. (2003). Corporate governance and performance in twentieth century Japan. Business and Economic History, 1(1), 1-36. Retrieved from https://www.semanticscholar.org/ paper/Corporate-Governanceand-Performance-in-Japan-Miyajima-Omi/92fb0b912f3433e62be3b8 1d860d0a429107c9ac

51. Monda, B., \& Giorgino, M. (2013). Corporate governance and shareholder value in listed firms: An empirical analysis in five countries (France, Japan, Italy, UK, USA). Corporate Ownership \& Control, 10(3), 36-50. https://doi. org/10.2139/ssrn.2227184

52. Mutuku, D. M. (2016). Effects of corporate governance on financial performance of savings and credit cooperative societies in Machakos and Athi river sub-counties

(Master's Thesis). Retrieved from http://repository.seku.ac.ke/handle/123456789/1908

53. Narwal, K. P., \& Jindal, S. (2015). The impact of corporate governance on the profitability: An empirical study of Indian textile industry. International Journal of Research in Management, Science \& Technology, 3(2), 81-85. Retrieved from https:// www.academia.edu/33712534/ The_Impact_of_Corporate_Governance_on_the_Profitability_An Empirical_Study_of_Indian_Textile_Industry

54. Ojeka, S. A., Iyoha, F. O., Ikpefan, O. A., \& Osakwe, C. (2017). Does reformed code of corporate governance 2011enhance the market performance of the firms in Nigeria? International Journal of Economic Performance, 11(1), 155164. Retrieved from http://eprints. covenantuniversity.edu.ng/8505/

55. Okafor, F. O. (2011). Fifty Years of Banking Sector Reforms in Nigeria (1960-2010) (Past Lessons - Future Imperatives). Enugu, Nigeria: Ezu Books Ltd. Retrieved from https://openlibrary.org/works/ OL16703970W/Fifty_years_of_ banking_sector_reforms_in_Nigeria_1960-2010

56. Okoye, L. U., Erin, O. A., Ahmed, A., \& Areghan, I. (2017). Corporate governance and financial sustainability if microfinance institutions in Nigeria. In Proceedings of the $29^{\text {th }}$ International Business Information Management Association (IBIMA) Conference (pp 4035-4045). Vienna, Austria.

57. Okoye, L. U., Evbuomwan, G. O., Achugamonu, U., \& Araghan, I. (2016). Impact of corporate governance on the profitability of the Nigerian banking sector. ESUT Journal of Accountancy, 7(1), 281292. Retrieved from http://eprints. covenantuniversity.edu.ng/8197/1/ CORPORATE\%20GOVERNANCE_EJA\%207\%20\%281\%29. pdf

58. Olayiwola, K. T. (2018). The effect of corporate governance on financial performance of listed companies in Nigeria. European Journal of Accounting, Auditing, and Finance
Research, 6(9), 85-98. Retrieved from https://www.eajournals.org/ wp-content/uploads/The-Effectof-Corporate-Governance-onFinancial-Performance-of-ListedCompanies-in-Nigeria.pdf

59. Olokoyo, F. O., Adegboye, F. B., Okoye, L. U., Evbuomwan, G. O., \& Adebo, A. E. (2019). Corporate governance and deposit money banks performance in Nigeria. In Proceedings of INTCESS 2019 - $6^{\text {th }}$ International Conference on Education and Social Sciences. Dubai, UAE. Retrived from http:// www.ocerints.org/intcess19_epublication/papers/213.pdf

60. Ongore, V. O., Peter, O. K., Ogutu, M., \& Bosire, E. M. (2015). Board composition and financial performance: Empirical analysis of companies listed at the Nairobi Securities Exchange. International Journal of Economics and Financial Issues, 5(1), 23-43. Retrieved from https://www.econjournals.com/ index.php/ijefi/article/view/806/pdf

61. Orozco, L. A., \& Vargas, J. (2018).

Trends on the relationship between board size and financial and reputational corporate performance: The Colombian case. European Journal of Management and Business Economics, 27(2), 183-197. https://doi.org/10.1108/ EJMBE-02-2018-0029

62. Oyarzún, C. A. (2011). Institutional shareholders and corporate governance: Do institutional shareholders have an active participation in preventive governance in the United Kingdom? And if so, how? Revista Chilena de Derecho, 38(1), 9-32. http://dx.doi.org/10.4067/S071834372011000100002

63. Pathan, S., Skully, M., \& Wickremanayake, J. (2007). Board size, independence and performance: An analysis of Thai banks. Asia-Pacific Financial Markets, 14, 211-227. http://dx.doi. org/10.1007/s10690-007-9060-y

64. Patibandla, M. (2006). Equity pattern, corporate governance and performance: A study of India's corporate sector. Journal of Economic Behavior and 
Organization, 59(1), 29-44. https:// doi.org/10.1016/j.jebo.2004.04.004

65. Pfeffer, J., \& Salancik, G. R. (1978). The External Control of Organizations: A Resource Dependence Perspective. Harper \& Row, New York, NY.

66. Raihan, M. Z., \& Hoque, K. E. (2013). Impact of corporate governance practices in some selected private banks in Bangladesh. Actual Problems of Economics, 11(149), 484-493. Retrieved from https://umexpert. um.edu.my/public_view.php?type= publication\&row=MjkzOTE\%3D

67. Roodposhti, F. R., \& Chashmi, S. N. (2010). The effect of board composition and ownership concentration on earnings management: Evidence from Iran, World Academy of Science. International Journal of Economics and Management Engineering, 4(6), 673-679. doi.org/10.5281/zenodo. 1079562

68. Salim, S. I. A., \& Iskandar, T. B. M. (2017). The effect of corporate governance on the financial performance of Jordanian corporations insurance sector. International Sciences of Management Journal, 2(2), 5-15. Retrieved from https://www. slideshare.net/Hum1/the-effect-ofcorporate-governance-on-the-financial-performance-of-jordaniancorporations-insurance-sector

69. Sanan, N. K. (2016). Board Gender Diversity, Financial and Social Performance of Indian Firms. Vision, 20(4), 361-367. https://doi.org/10.11 77\%2F0972262916673006

70. Sani, A. B., Aliyu, A. A., \& Bakare, T. O. (2019). Effect of corporate governance on financial performance of deposit money banks in Nigeria. Asian Journal of Economics, Business and Accounting, 13(3), 1-11. https://doi.org/10.9734/ ajeba/2019/v13i330175

71. Sarpal, S., \& Singh, F. (2013). Board Size and Corporate Performance: An Empirical Investigation. International Journal of Business Ethics in Developing Economies, 2(1), 1-8. Retrieved from http://www. publishingindia.com/GetBrochure.
aspx?query=UERGQnJvY2h1cmV zfC8xNzE2LnBkZnwvMTcxNi5w$\mathrm{ZGY}=$

72. Shivaani, M. V., Jain, P. K., \& Yadav, S. S. (2017). Perceptual Mapping of Capital Budgeting Techniques: Empirical Evidence from Corporate Enterprises in India. Research Bulletin, 42(4), 106-112. Retrieved from http://www.icmai-rnj.in/index. $\mathrm{php} / \mathrm{rb} /$ article/view/111594

73. Soludo, C. C. (2004). Consolidating the Nigerian banking industry to meet the challenges of the $21^{\text {st }}$ century. Address to a special meeting of the Bankers Committee, Abuja, $6^{\text {th }}$ July 2004. BIS Review. Retrieved from https://www.bis.org/review/ r040727g.pdf

74. Spanos, L. J. (2005). Corporate governance in Greece: Developments and policy implications. Corporate Governance: The International Journal of Business in Society, 5(1), 15-30. Retrieved from https://mpra.ub.unimuenchen.de/42901/

75. Strøm, R. Ø., D’Espallier, B., \& Mersland, R. (2014). Female leadership, performance, and governance in microfinance institutions. Journal of Banking and Finance, 42, 60-75. https://doi. org/10.1016/j.jbankfin.2014.01.014

76. Surya, B. G. C. (2016). Corporate governance and firm performance: Empirical evidence from India. Journal of Business Management Research, 1(2), 48-65. https://doi org/10.3126/jbmr.v1i2.15663

77. Tata, S. V., \& Sharma, M. (2012). Corporate governance mechanisms and firm performance: A study of Indian firms. Journal of Commerce and Accounting Research, 1(1), 11-17. Retrieved from http://www. publishingindia.com/jcar/47/ corporate-governance-mechanismsand-firm-performance-a-study-ofindian-firms/126/984/

78. Thuraisingam, M. R. (2013). The effects of corporate governance on company performance: Evidence from Sri Lankan financial services industry. Journal of Economics and Sustainable Development, 4(17), 103-109. Retrieved from https:// iiste.org/Journals/index.php/JEDS/ article/view/9017
79. Usman, S. H., \& Yero, J. I. (2012). Ownership concentration and earnings management practice of Nigerian listed conglomerates. American International Journal of Contemporary Research, 2(7), 157171. Retrieved from http://www. aijcrnet.com/journals/Vol_2_No_7_ July_2012/19.pdf

80. Uwuigbe, O. R. (2011). Corporate governance and financial performance of banks: A study of listed banks in Nigeria (Ph.D. Thesis). Covenant University, Ota, Nigeria. Retrieved from http:// eprints.covenantuniversity.edu. ng/694/

81. Van Ness, R. K., Miesing, P., \& Kang, J. (2010). Board of director composition and financial performance in a Sarbanes-Oxley world. Academy of Business and Economics Journal, 10(5), 56-74. Retrieved from https://www.albany. edu/faculty/vanness/AA/Abstracts/ DirectorSOX.pdf

82. Vo, D., \& Phan, T. (2013). Corporate governance and firm performance: Empirical evidence from Vietnam. Retrieved from http://digital.lib.ueh. edu.vn/handle/UEH/55153

83. Yang, I. H., Yan, L.I., Li, Y., \& Yang, H. (2012). Disclosure and the cost of equity capital: An analysis at the market level. Retrieved from https://pdfs.semanticscholar.org/421f/f504e55aab59ce68ce0ecb938496aa4cc8fd.pdf

84. Yauri, M. N., Muhammad, K., \& Kaoje, N. A. (2013). Corporate governance and performance of Nigerian deposit money banks in post-consolidation era. International Journal of Current Research, 5(6), 1389-1397. Retrieved from https:// www.academia.edu/3725650/ Corporate_Governance_and_Performance_of_Nigerian_Deposit_ Money_Banks_in_Post_Consolidation_Era

85. Zandi, M. (2009). Financial Shock. New Jersey: Pearson Education Inc.

86. Zsohar, P. (2012). Short introduction to the generalized method of moments. Hungarian Statistic Review (Special Number), 16, 150-170. Retrieved from https://www.ksh.hu/statszemle_archive/2012/2012_K16/2012 K16_150.pdf 